Primljeno: 15/9/2019

UDK: 373.5.091.312:004.774(497.571:497.542)

Stručni rad

\title{
ANALIZA ZASTUPLJENOSTI TIMSKOGA RADA NA MREŽNIM STRANICAMA SREDNJOŠKOLSKIH INSTITUCIJA U ISTARSKOJ I BRODSKO-POSAVSKOJ ŽUPANIJI
}

\section{Ljiljana Tadić Komadina}

Fakultet za odgojne i obrazovne znanosti Sveučilište Jurja Dobrile u Puli ljkomadi@gmail.com

Dea Lazić Hasanagić

Fakultet za odgojne i obrazovne znanosti Sveučilište Jurja Dobrile u Puli

\section{Luka Pongračić}

Fakultet za odgojne i obrazovne znanosti Sveučilište Jurja Dobrile u Puli 


\section{SAŽETAK}

Timski rad je u današnjem kulturno pluralističkom društvu postao predmetom uspješnoga poslovanja koji se počeo primjenjivati i u odgojno-obrazovnim institucijama. Jedan od načina prikazivanja imidža škole je na mrežnim stranica pa se njihovom analizom sadržaja može stvoriti slika o pridavanju važnosti provođenja timskoga rada u školama. Cilj je ovog rada na temelju mrežnih stranica svih srednjih škola u Istarskoj i Brodsko-posavskoj županiji utvrditi koliko se često objavljuju tekstovi s ključnom riječi ,timski rad“' u kojem kontekstu i komu su namijenjeni. Svrha istraživanja je prikupiti podatke o zastupljenosti ključnoga pojma „timski rad“ na mrežnim stranicama spomenutih srednjih škola. Rezultati analize dali su odgovor na pitanje je li timski rad postao dio obrazovne politike u srednjim školama. Nažalost, pokazalo se da se timskom radu ne pridaje veći značaj u objavama koje se mogu naći na mrežnim stranicama navedenih škola.

Ključne riječi: mrežne stranice, obrazovna politika, odgojno-obrazovne institucije, srednje škole, timski rad 


\section{UVOD}

Timski rad je u suvremenom dobu globalizacije i modernizacije prepoznat kao važna vrijednost i neminovna metoda rada kojom se postižu bolji rezultati u svim djelatnostima, pa tako i u obrazovanju. Taj je fenomen prvotno prepoznat u menadžmentu, čime se uspostavio novi način poslovanja koji je direktno vezan za pojedinca. Naime, promjene koje su se dogodile tiču se redizajniranja poslovnih procesa koji naglašavaju važnost dijeljenja znanja, vještina i iskustava s drugima te povezivanje ljudi u timove (Džubur, 2003).

Iako se pojmovi često koriste kao sinonimi, važno je napomenuti da svaka grupa nije ujedno i tim. Za razliku od grupe koja izvršava radne zadatke po nalogu, tim je pojam koji opisuje fleksibilnost i autonomiju. Dok su radne grupe najčešće poslovne, organizacijske i tehnološke prirode, a njihov rezultat rada ukupnost pojedinačnih doprinosa grupe, timovi se okupljaju radi razvoja, odnosno stvaralaštva (Skupnjak, 2018). Zbog međusobnoga poticanja članova tima na ostvarenje zajedničkih ciljeva te pozitivnoga utjecaja na moral grupe, timskim se radom dolazi do sinergije, odnosno većega efekta unutar tima (Antolović, Bošković, 2017).

Postoje različite definicije tima. Tudor i Srića $(2006,22)$ ga definiraju kao „malu skupinu ljudi u kojih zajednički ciljevi imaju prednost i koji usklađeno djeluju kako bi ih ostvarili“, dok Miljković i Rijavac (prema Skupnjak, 2018, 2) govore o „manjoj grupi ljudi s komplementarnim znanjima i vještinama, koji zajedno rade kako bi ostvarili cilj za koji se smatraju zajednički odgovornima“. Prema Tipuriću (1999) timski rad pretpostavlja nekolicinu ljudi koji preuzimaju određenu ulogu te zajedničkim radom, posvećenošću i predanošću postavljenom cilju, kao i povjerenjem, ostvaruju proaktivni pristup radnom zadatku. Dodaje kako je timski rad planirano integriranje kompetencija članova tima u svrhu rješavanja istoga zadataka, s ciljem zadovoljenja kupca ili korisnika usluga, proizvodnosti i profita te zadovoljstva zaposlenika. Maxwell (2003) timski rad smatra procesom, a pod pojmom tima podrazumijeva ne samo kolege u organizaciji već i supružnike $u$ braku. Autor napominje da je timski rad potreban kako bi ostvarili svoje snove, bez obzira čime se u životu želimo baviti.

Važno je napomenuti da timovi različitih organizacija dijele zajednička obilježja: 1) tim nije sam sebi svrha već je smisao postojanja tima učinak, 2) izgradnja jake etike učinka, 3) sklonost individualizmu koja ne ugrožava timski opstanak te 4) jasno postavljanje ciljeva i prihvaćanje odgovornosti za njih (Antolović, Bošković, 2017).

Kako bi radni tim djelovao uspješno, potrebne su određene kompetencije članova tima, a to su: empatija, suradnja i zajednički trud, otvorena međusobna 
komunikacija, postavljanje jasnih normi i očekivanja i suočavanje s članovima koji loše rade, samosvijest i samokritičnost (procjena svojih sposobnosti i slabosti u timu), inicijativa i zauzimanje proaktivnoga stajališta prema rješavanju problema, samopouzdanje i motivacija, fleksibilnost, organizacijska svijest te donošenje prave odluke (Nikić, 2004).

Skupnjak (2018) navodi prednosti rada u timu: lakše rješavanje konflikata i donošenja odluka, međusobno razumijevanje članova tima, živa i aktivna atmosfera te osjećaj pripadnosti i predanosti zajedničkoj viziji. Ipak, pri stvaranju timova valja biti oprezan te se povremeno osvrtati na njegovo održavanje, razvijanje i napredovanje kako bi se izbjegao razdor među članovima.

\section{POVIJEST I MODELI PROUČAVANJA TIMOVA}

Tijekom prve polovice 20. stoljeća zabilježene su prve ideje o stvaranju i proučavanju timskoga rada napuštanjem industrijske epohe i ulaskom u tzv. informacijsku epohu (Katunarić, 1999). Budući da je dinamika življenja sve brža, ključnu ulogu u stvaranju pluralističkoga društva imaju novi mediji koji informacije čine lako dostupnim, a upravo zbog toga se vrlo brzo i mijenjaju. Obrat u promišljanju čovjekove uloge u organizaciji dogodio se nakon tzv. Hawthornškoga istraživanja nastaloga pod utjecajem tzv. načela znanstvenoga menadžmenta kojeg je uveo F. Taylor 1911. godine. Taylor je, naime, promatrajući radni učinak pojedinaca zaključio da je potrebno eliminirati sve nepotrebne i neproduktivne radnje te navodi da je važno razgraničiti metode rješavanja problema i odlučivanja (Buhač, 2017b). Međutim, takav je model naišao na mnogobrojne kritike koje se uglavnom odnose na detaljno propisane radne zadatke (task analysis) date od eksperta (Waldow, 2012). Hawthornško istraživanje provedeno je u Sjedinjenim Američkim Državama tijekom 20-ih i 30-ih godina 20. stoljeća od strane E. Maya i F. Roethlisbergera. Cilj istraživanja bio je otkriti utjecaj fizičkoga okruženja na radnika, a rezultati su pokazali da je radni učinak povezan s društvenim položajem i socijalnim tretmanom radnika. Tijekom godina, Hawthornška istraživanja stekla su status mita zbog čega se u znanstvenu terminologiju uveo i pojam „hawthornški efekt“ jer ponovljena istraživanja S. Roethlisbergera (1941, prema: Wickström, Bendix, 2006), P. Rossi i H. Freemana (1989, prema: Wickström, Bendix, 2006), R. Kahna (1975, prema Wickström, Bendix, 2006) i drugih nisu potvrdila pozitivne učinke. Akademska je zajednica tako zaključila da je povećanje produktivnosti u navedenome istraživanju moglo biti povezano s nadzorom i svijesti o postojanju eksperimenta (Wickström, Bendix, 2006). 
J. F Bobbitov ${ }^{1}$ koncept standardizacije obrazovanja iz prve polovice 20. stoljeća odnosi se prvenstveno na poboljšanje školskoga sistema uvođenjem kurikuluma u školski sustav oslanjajući se na taylorističke principe. On navodi da se zahtjevi za organizacijom, vođenjem i provjerom u menadžmentu u principu ne razlikuju od zahtjeva za organizacijom, provođenjem i evaluacijom nastavnoga sata. Bobbit ide korak dalje pa terminologiju iz područja proizvodnje prenosi na obrazovanje te objašnjava da je učenik proizvod koji je u procesu stvaranja dobio potrebna znanja, vještine i iskustva. Osim toga, školu opisuje kao tvornicu, dok su učitelji i učenici radnici, gdje su učenici tzv. ultimate workers jer je proces direktno vezan za njih. Direktora tvornice poistovjećuje se s ravnateljem škole, a kupac je društvo sa svojim potrebama i zahtjevima. Može se zaključiti da je proizvod, tj. učenik stvoren prema zahtjevima kupca, odnosno društva u svrhu zadovoljenja njihovih potreba. Bobbit tvrdi da je standardizacija proizvoda nužna, kako u industriji tako i u školi, te objašnjava da je potrebno pažljivo sagledati potrebe zajednice na temelju kojih će se onda odrediti njihove potrebe. Isti zaključuje da uloga učitelja nije razviti najveći mogući potencijal kod učenika već ga oblikovati prema potrebama tržišta (Waldow, 2012).

Istraživanja i ispitivanja rada u timu pokazala su uglavnom pozitivne rezultate. Psiholog B. Tuckman uveo je 1965. godine model koji opisuje četiri opće faze razvoja tima: formiranje (forming), naviranje (storming), normiranje (norming) i izvedba (performing) (Egolf i Chester, 2013). Formiranje je termin koji se koristi za upoznavanje pojedinaca s ostatkom članova grupe, što je često povezano s osjećajem nesigurnosti. Nakon početne faze upoznavanja slijedi faza definiranja načina rada koja se naziva još i naviranje. Ako se u ovoj fazi susretnu dvije ili više dominantnih osobina članova tima, moguće je da će se pojaviti problemi u radnome procesu, zbog čega se savjetuje prisustvo moderatora koji će pozitivno usmjeravati slijed događaja. Nakon definiranja načina rada, tim ulazi u iduću fazu koja se naziva normiranje. Karakteristično za ovu fazu je definiranje uloga pojedinaca u timu, nakon čega slijedi rad, odnosno izvedba. Ovaj je model kasnije nadopunjen petom fazom koja se odnosi na razlaz tima ili okončanje, što je Tucker nazvao adjouring (Kauffeld, 2014).

\section{TIMSIKI RAD U ODGOJU I OBRAZOVANJU}

Suvremeni pristupi znanosti o odgoju i obrazovanju dovode u pitanje učinkovitost tradicionalne metode predavačke nastave i natjecateljskoga učenja, pa se i u rječnik moderne teorije odgoja i obrazovanja uvodi pojam timskoga rada. Osim

1 Američki psiholog John Franklin Bobbit (1876. - 1956.) predstavnik je „the new breed of efficiency minded educators", a njegova najpoznatija djela su The curriculum (1918) i How to make a curriculum (1924). 
timskoga rada učenika, u odgojno se obrazovnim institucijama prepoznaju i drugi timovi različitih profila koji međusobno surađuju u svrhu odgoja, preodgoja, obrazovanja ili pružanja pomoći učenicima. Ravlić (1996) govori o važnosti timskoga praćenja osobina i sposobnosti učenika od strane pedagoga, psihologa i razrednika koji bi trebali donijeti odgovarajuće zaključke vezane uz njihove osobine i sposobnosti, nakon čega slijedi timski rad s roditeljima, ako je on potreban. Skupnjak (2018), osim timske suradnje školskih stručnjaka i nastavnika u vezi s misijom i vizijom škole te napretkom učenika, spominje i timsku suradnju općih i specijalnih edukatora u vezi s državnim standardima i okvirnim nastavnim programom. Brajša $(1994,178)$ piše o reflektirajućem timu kao „suvremenoj timskoj metodi rješavanja kompleksnih problema" gdje je na jednoj strani sustav s problemom, a na drugoj reflektirajući tim. Upravo ovu metodu smatra pretpostavkom demokratskoga dijaloga, kako u školi tako i u obitelji, poduzeću ili domovini.

U hrvatskim se odgojno-obrazovnim dokumentima timski rad prvi puta spominje tek 2006. godine u Hrvatskome nastavnom planu i programu, i to u kontekstu timskoga planiranja. U tome se dokumentu govori o nedostacima dotadašnje individualne izrade plana i programa te prednostima timskoga planiranja (učenika, učitelja, stručnih suradnika i vanjskih članova zajednice) kao preduvjeta ostvarivanja uspjeha. Ondje stoji i to da bi ravnatelji i stručni suradnici trebali poticati timski rad svih djelatnika i polaznika škole te da je timski rad poželjan i u projektima, aktivnostima, kao i u svim nastavnim predmetima.

Kobayashi je izradio „model stvaranja tima u obrazovnim institucijama:

1.timski rad je nezamisliv

2.pojedini dijelovi školskog sustava priželjkuju si timove

3. formaliziran i nestvaran timski rad

4. stvarni timski rad i autonomna radna grupa

5. isprepleten timski rad i restrukturiranje sustava" (Carle, 2010, 85).

Bognar i Matijević $(2002,258)$ timsku nastavu definiraju kao „skup nastojanja usmjerenih na reorganizaciju nastavničkog kolektiva s ciljem da se unaprijedi nastava, i to tako da dva ili više nastavnika dijele odgovornost za pripremanje, planiranje, realizaciju i vrednovanje izvođenja nastave za dvije obrazovne skupine ili više njih“.

Najčešće govorimo o trima oblicima timske nastave:

1) horizontalnoj timskoj nastavi u koju su uključeni nastavnici iste specijalnosti paralelnih razreda iste škole

2) vertikalnoj timskoj nastavi u koju su uključeni nastavnici različitih specijalnosti istih razreda iste škole $\mathrm{i}$

3) kombiniranoj timskoj nastavi u kojoj sudjeluju stručnjaci različitih područja na razini škole. 
U novije doba govorimo i o suradničkome učenju koje se zasniva na timskome radu, stavljajući pritom naglasak na aktivno uključenje učenika u nastavni proces (Bognar, Matijević, 2005). Johnson-Johnson napominju da prije početka suradničkoga učenja treba formirati grupe koje, uz primjenu aktivnosti za razvijanje timskoga duha, postaju timovi, odnosno osjećaju zajedništvo te žele i mogu surađivati. Autori stoga navode preduvjete za uspjeh suradničkoga učenja: razvijene socijalne vještine, rad u grupama do četiri osobe, pozitivna uzajamna ovisnost članova, individualna odgovornost svakoga člana grupe i promišljanje o zajedničkome procesu (Brüning, Saum, 2008).

U novije se vrijeme u odgoju i obrazovanju počeo koristiti termin školski/ pedagoški/obrazovni menadžment. Pri tome mislimo na menadžment koji se odvija u specifičnome društvenom, gospodarskom i obrazovnom kontekstu u kojem postoji svojevrstan oblik natjecanja između odgojno-obrazovnih institucija (Levačić, 1995; prema Vidović i sur., 2009). To je menadžment kojim se upravlja cjelokupnom djelatnošću obrazovnoga područja, a podrazumijeva stručno područje, znanstvenu disciplinu, profesiju i funkciju (Buhač, 2017a). Uloga školskoga menadžmenta je aktivno podržavati timski rad, kako među učenicima tako i među nastavnicima te drugim obrazovnim djelatnicima. Stvaranje timova započinje od najvišega nivoa škole, odnosno uprave koja aktivno provodi i promiče timski rad te kroz razne procese i projekte daje dobar primjer provođenja i pozitivnih ishoda takvoga djelovanja (Carle, 2010).

Postavlja se pitanje u kojoj je mjeri zastupljen i promiče li se timski rad u srednjim školama u Republici Hrvatskoj. Cilj je ovoga rada analizirati mrežne stranice srednjih škola u Istarskoj i Brodsko-posavskoj županiji i na temelju rezultata prikazati u kojoj se mjeri promovira timski rad te je li timski rad dio obrazovne politike, odnosno na kojemu se koraku nalaze naše srednje škole kada je u pitanju stvaranje tima u obrazovnim institucijama.

\section{METODOLOGIJA}

\section{Postupak i zadaci istraživanja}

U novije se vrijeme sve više naglašava komunikacijska strategija imidža škole pa se sve veća pozornost pridaje komunikaciji na mrežnim stranicama škola. Prema CARNET-u (2008), usluzi realiziranoj u suradnji s Ministarstvom znanosti i obrazovanja, od 1. ožujka 2007. godine omogućen je Sustav za upravljanje sadržajem (CMS) za jednostavno postavljanje i ažuriranje mrežnih stranica za sve osnovne i srednje škole. U svrhu ovoga istraživanja prikupljeni su i analizirani 
podaci dostupni na mrežnim stranicama svih srednjih škola u Istarskoj županiji ${ }^{2}$ i Brodsko-posavskoj županiji ${ }^{3}$. Analizirana je zastupljenost ključne riječi „timski rad“ pomoću tražilice na mrežnim stranicama škola, a podaci su potom posloženi prema:

1. naslovu

2. godini objave

3. namjeni

4. kontekstu.

U Istarskoj su županiji analizirane mrežne stranice sve 24 srednje škole, a u Brodsko-posavskoj županiji svih 11.

Glavni je zadatak ove analize mrežnih stranica ustanoviti koliko i u kojem kontekstu škole spominju timski rad na svojim mrežnim stranicama. Analizom članaka u kojima se spominje timski rad ustanovit će se komu su članci namijenjeni - roditeljima, učenicima, nastavnicima i sl. Drugi je zadatak ustanoviti u kojemu se kontekstu spominje pojam ,timski rad" - projekti, obavijesti, upute, izvješća i sl.

2 Gimnazija Pula http://www.gimnazija-pula.skole.hr/?cal_ts=746834400, Talijanska srednja škola Dante Alighieri u Puli http://www.ss-dante-pula.skole.hr/, Tehnička škola u Puli http://ss-tehnickapu.skole.hr/?cal_ts=28854000, Ekonomska škola u Puli http://ss-ekonomska-pu.skole.hr/skola?cal_ ts=1514761200, Gimnazija i strukovna škola Jurja Dobrile u Pazinu http://www.gssjd.hr, Pazinski kolegij - klasična gimnazija s pravom javnosti http://www.pazinski-kolegij.hr/, Srednja škola Mate Balote u Poreču http://ss-mbalote-porec.skole.hr/?news_archive_view=1\&news_archive_year=2017, Srednja škola Zvane Črnje u Rovinju http://ss-zcrnje-rovinj.skole.hr/?news_id=305, Strukovna škola Eugena Kumičića u Rovinju http://ss-strukovna-ekumicica-rovinj.skole.hr/, Srednja škola Mate Blažine u Labinu http://www.ssmb.hr/, Gimnazija i strukovna škola Jurja Dobrile u Pazinu https:// www.gssjd.hr/, Gospodarska škole Buje http://www.ss-gospodarska-buje.skole.hr/, Industrijsko obrtnička škola Pula http://ss-ios-pu.skole.hr/, Medicinska škola Pula http://www.ss-medicinska-pu. skole.hr/, Privatna gimnazija Jurja Dobrile www.gimnazija-privatna-jdobrile-pu.skole.hr, Talijanska srednja škola Leonardo da Vinci Buje http://www.ss-leonardodavinci-buje.skole.hr/, Srednja škola Vladimir Gortan Buje http://www.ss-vgortan-buje.skole.hr/, Srednja škola Buzet http://www.ss-buzet. skole.hr/, Strukovna škola Pula http://www.ss-strukovna-pu.skole.hr/, Škola primijenjenih umjetnosti i dizajna Pula www.ss-primijenjenihumjetnostiidizajna-pu.skole.hr, Škola za odgoj i obrazovanje - Pula http://ss-odgoj-obrazovanje-pu.skole.hr/, Škola za turizam, ugostiteljstvo i trgovinu Pula www.lipa-pu.hr, Škola za turizam, ugostiteljstvo i trgovinu Rovinj http://www.smsir.hr/, Turističkougostiteljska škola Antona Štifanića u Poreču http://ss-astifanica-porec.skole.hr/.

3 Gimnazija Matija Mesić u Slavonskom Brodu http://gimnazija-mmesic-sb.skole.hr/, Srednja škola Antuna Matije Reljkovića u Slavonskom Brodu http://ss-mareljkovica-sb.skole.hr/, Klasična gimnazija fra. Marijana Lanosovića u Slavonskom Brodu http://gimnazija-framarijanalanosovica. $\mathrm{hr} /$, Ekonomsko-birotehnička škola Slavonski Brod http://ss-ekonomsko-birotehnicka-sb.skole. hr/, Obrtnička škola Slavonski Brod http://ss-obrtnicka-sb.skole.hr/, Tehnička škola Slavonski Brod http://ss-tehnicka-slavonski-brod.skole.hr/, Industrijsko-obrtnička škola Slavonski Brod http://ss-industrijsko-obrtnicka-sb.skole.hr/, Srednja medicinska škola Slavonski Brod http:// www.ss-medicinska-sb.skole.hr/, Elektrotehnička i ekonomska škola Nova Gradiška http://sselektrotehnickaiekonomska-ngradiska.skole.hr/, Industrijsko-obrtnička škola Nova Gradiška https:// iosng.hr/ , Gimnazija Nova Gradiška http://gimnazija-nova-gradiska.skole.hr/. 


\section{Cilj, svrha, hipoteza rada}

Cilj istraživanja je prikazati u kojoj se mjeri promovira timski rad na mrežnim stranicama srednjih škola u Istarskoj i Brodsko-posavskoj županiji.

Svrha istraživanja je prikupiti podatke o zastupljenosti ključnoga pojma „timski rad“ na mrežnim stranicama svih srednjih škola u Istarskoj i Brodsko-posavskoj županiji.

Polazišna hipoteza ovoga istraživanja je:

H1 - Timski rad dovoljno je zastupljen i promoviran na mrežnim stranicama srednjoškolskih institucija u Istarskoj i Brodsko-posavskoj županiji.

\section{REZULTATI}

Mrežne stranice srednjih škola koje bi trebale predstavljati vizualni identitet institucije i služiti kao komunikacijski kanal između škole i šire javnosti pokazale su da, od sveukupno 24 srednje škole u Istarskoj županiji, samo 11 ima objave vezane uz timski rad na svojim mrežnim stranicama. U Brodsko-posavskoj županiji od 11 srednjih škola, 7 škola ima objave koje se tiču timskoga rada. Ukupno gledano, u obje županije, tek 18 od 35 srednjih škola imaju objave u vezi s timskim radom, što s postotkom od $51 \%$ čini samo polovicu srednjih škola (Tablica 1.)

Tablica 1.: Objave na mrežnim stranicama škola vezane uz timski rad

\begin{tabular}{clc}
\hline \multicolumn{1}{c}{ Županija } & \multicolumn{1}{c}{ Škola } & Postotak \\
\hline & Gimnazija Pula & \\
& Tehnička škola u Puli & \\
& Ekonomska škola u Puli & \\
& Gimnazija i strukovna škola Jurja & \\
& Dobrile u Pazinu & \\
& Srednja škola Zvane Črnje Rovinj & \\
& Gimnazija i strukovna škola Jurja & $46 \%$ \\
& Dobrile u Pazinu & \\
Gospodarska škola Buje & \\
Medicinska škola Pula & \\
& Srednja škola Vladimir Gortan & \\
& Buje & \\
& Škola za odgoj i obrazovanje - & \\
& Pula & \\
& Turističko-ugostiteljska škola & \\
& Antona Štifanića u Poreču &
\end{tabular}




\begin{tabular}{llc}
\hline \multicolumn{1}{c}{ Županija } & \multicolumn{1}{c}{ Škola } & Postotak \\
\hline & Klasična gimnazija fra. Marijana & \\
& Lanosoviča u Slavonskom Brodu \\
& Tehnička škola Slavonski Brod \\
& Industrijsko-obrtnička škola & \\
& Slavonski Brod \\
& Srednja medicinska škola & \\
Slavonski Brod & \\
& Elektrotehnička i ekonomska & \multirow{2}{*}{$64 \%$} \\
& škola Nova Gradiška & \\
& Industrijsko-obrtnička škola & \\
& Nova Gradiška \\
& Gimnazija Nova Gradiška & \\
\hline Ukupno & 18 od 35 & $51 \%$ \\
\hline
\end{tabular}

Navedene su škole na svojim mrežnim stranicama sveukupno spomenule timski rad 71 put. Analiza arhive vijesti na mrežnim stranicama pokazala je da Gimnazija i strukovna škola Jurja Dobrile u Pazinu te Škola za odgoj i obrazovanje u Puli prednjače s 12 objava od 2009. do 2018. godine.

Prema dobivenim rezultatima pokazalo se da se u Istarskoj županiji Škola za odgoj i obrazovanje u Puli najčešće posvećuje temama vezanim za timski rad sa 6,3 $\%$. Timskom se radu u sveukupnom zbroju 11 istarskih srednjih škola izvedeno iz matrice tablica vezanih za timski rad pridaje prosječno ukupno $1,6 \%$ pozornosti. Treba napomenuti kako 13 srednjih škola u Istarskoj županiji, što je više od polovice, ni u jednoj objavi ne spominju timski rad.

U Brodsko-posavskoj županiji situacija je lošija. Najviše objava vezanih uz timski rad posvetila je Elektrotehnička i ekonomska škola Nova Gradiška sa samo $0,74 \%$ udjela. U sveukupnome zbroju postotak objava svih škola u županiji iznosi izrazito niskih $0,39 \%$, dok 4 srednje škole na svojim mrežnim stanicama uopće ne spominju timski rad.

Ukupno gledano, u obje promatrane županije, samo 0,97 \% objava spominje timski rad u nekome obliku izvedenice toga pojma. Ovaj mali postotak ukazuje na izrazito malu zastupljenost ovoga pojma, dok 49 \% srednjih škola u svojoj arhivi nema nijednu obavijest koja spominje bilo koji oblik timskoga rada (Tablica 2.). Ovaj podatak ukazuje na to da polovica promatranih srednjih škola na svojim mrežnim stranicama nikada nije spomenula timski rad. 
Tablica 2.: Objave vezane uz timski rad u arhivi vijesti mrežnih stranica škola

\begin{tabular}{|c|c|c|c|c|}
\hline \multicolumn{5}{|c|}{ Istarska županija } \\
\hline Škola & $\begin{array}{l}\text { Godina } 4 \text { / timski } \\
\text { rad/ sveukupno } \\
\text { objava te godine }\end{array}$ & $\begin{array}{l}\text { Timski rad } \\
\text { sveukupno }\end{array}$ & $\begin{array}{l}\text { Sveukupno } \\
\text { objava u arhivi }\end{array}$ & Postotak $^{5}$ \\
\hline Gimnazija Pula & $\begin{array}{c}2017 . / 1 / 66 \\
2016 . / 2 / 108 \\
2015 . / 2 / 17 \\
2010 . / 1 / 1 \\
\end{array}$ & 9 & 268 & $3,36 \%$ \\
\hline Tehnička škola u Puli & $\begin{array}{l}2012 . / 1 / 44 \\
2011 . / 1 / 26\end{array}$ & 2 & 272 & $0,73 \%$ \\
\hline Ekonomska škola Puli & $\begin{array}{l}2016 . / 1 / 38 \\
2015 . / 1 / 26\end{array}$ & 2 & 387 & $0,52 \%$ \\
\hline $\begin{array}{l}\text { Gimnazija i strukovna škola } \\
\text { Jurja Dobrile u Pazinu }\end{array}$ & $\begin{array}{l}2018 . / 2 / 83 \\
2017 . / 1 / 87 \\
\end{array}$ & 3 & 690 & $0,43 \%$ \\
\hline $\begin{array}{l}\text { Srednjąškola Zvane Črnje } \\
\text { Rovinj }\end{array}$ & 2018./1 & 4 & - & - \\
\hline $\begin{array}{l}\text { Gimnazija i strukovna škola } \\
\text { Jurja Dobrile u Pazinu }\end{array}$ & $\begin{array}{l}2018 . / 4 / 76 \\
2017 . / 3 / 87 \\
2016 . / 1 / 68 \\
2014 . / 1 / 75 \\
2013 . / 1 / 76 \\
2012 . / 1 / 58 \\
2009 . / 1 / 40\end{array}$ & 12 & 705 & $1,7 \%$ \\
\hline Gospodarska škola Buje ${ }^{7}$ & $\begin{array}{l}\text { 2018./1/ } \\
\text { 2015./1/ } \\
\end{array}$ & 2 & - & - \\
\hline Medicinska škola Pula & 2019./1/42 & 1 & 232 & $0,4 \%$ \\
\hline $\begin{array}{l}\text { Srednja škola Vladimir } \\
\text { Gortan Buje }\end{array}$ & $\begin{array}{l}\text { 2018./1/17 } \\
\text { 2017./1/20 } \\
\text { 2016./1/24 }\end{array}$ & 3 & 244 & $1,2 \%$ \\
\hline $\begin{array}{l}\text { Škola za odgoj i obrazovanje } \\
\text { - Pula }\end{array}$ & $\begin{array}{l}2018 . / 2 / 25 \\
2017 . / 2 / 31 \\
2016 . / 1 / 23 \\
2015 . / 4 / 25 \\
2014 . / 2 / 29 \\
2013 . / 1 / 17 \\
\end{array}$ & 12 & 189 & $6,3 \%$ \\
\hline $\begin{array}{l}\text { Turističko-ugostiteljska škola } \\
\text { Antona Štifanića u Poreču }\end{array}$ & $\begin{array}{l}\text { 2018./1/40 } \\
\text { 2015./1/73 } \\
2012 . / 2 / 63 \\
2011 . / 1 / 41 \\
2008 . / 1 / 26 \\
\end{array}$ & 6 & 500 & $1,2 \%$ \\
\hline Ukupno Istarska županija & & 56 & 3487 & $1,6 \%$ \\
\hline
\end{tabular}

4 Postoje objave kojima je nepoznat datum.

5 Postotak se odnosi na objave s ključnom riječi timski rad u sveukupnome broju objava sačuvanih u arhivi.

6 Ne postoji arhiva objava.

7 Ne postoji arhiva objava. 


\begin{tabular}{lcccc}
\hline \multicolumn{5}{c}{ Brodsko-posavska županija } \\
\hline Škola & $\begin{array}{c}\text { Godina/ timski rad/ } \\
\text { sveukupno objava te } \\
\text { godine }\end{array}$ & $\begin{array}{c}\text { Timski rad } \\
\text { sveukupno }\end{array}$ & $\begin{array}{c}\text { Sveukupno } \\
\text { objava u arhivi }\end{array}$ & Postotak $^{8}$ \\
\hline $\begin{array}{l}\text { Klasična gimnazija fra. } \\
\text { Marijana Lanosovića u } \\
\text { Slavonskom Brodu }\end{array}$ & $\begin{array}{c}1 / 176 \\
\text { Tim za kvalitetu }\end{array}$ & 1 & 176 & $0.56 \%$ \\
\hline $\begin{array}{l}\text { Tehnička škola Slavonski } \\
\text { Brod }\end{array}$ & $2013 . / 1 / 149$ & 1 & 885 & $0,11 \%$ \\
\hline $\begin{array}{l}\text { Industrijsko-obrtnička škola } \\
\text { Slavonski Brod }\end{array}$ & $2012 . / 1 / 161$ & 1 & 939 & $0,1 \%$ \\
\hline $\begin{array}{l}\text { Srednja medicinska škola } \\
\text { Slavonski Brod }\end{array}$ & $\begin{array}{c}2019 . / 1 / 37 \\
2018 . / 1 / 104 \\
2017 . / 2 / 72\end{array}$ & 4 & 445 & $0.51 \%$ \\
\hline $\begin{array}{l}\text { Elektrotehnička i ekonomska } \\
\text { škola Nova Gradiška }\end{array}$ & $\begin{array}{l}2019 . / 2 / 53 \\
2018 . / 2 / 142 \\
2012 . / 1 / 31\end{array}$ & 5 & 673 & $0.74 \%$ \\
\hline $\begin{array}{l}\text { Industrijkso-obrtnička škola } \\
\text { Nova Gradiška }\end{array}$ & $2013 . / 1 / 18$ & 1 & 231 & $0.43 \%$ \\
\hline Gimnazija Nova Gradiška & $2018 . / 2 / 87$ & 2 & 442 & $0.45 \%$ \\
\hline $\begin{array}{l}\text { Ukupno Brodsko-posavska } \\
\text { županija }\end{array}$ & & 15 & 3791 & $0.39 \%$ \\
\hline Ukupno & 71 & 7278 & $0,97 \%$ \\
\hline
\end{tabular}

Nadalje, sagledaju li se sadržaji navedenih objava (Tablica 3.), može se zaključiti da se timski rad najviše spominje u kontekstu projekata, zatim natjecanja, a najmanje kao oblik fakultativne nastave, dok se kao oblik redovne nastave uopće ne spominje. Jedan od problema današnjega obrazovnoga sustava je nezainteresiranost učenika za nastavni sadržaj, a za što je moguće djelomično odgovorna i prevelika socijalna distanca između nastavnika i učenika te učenika međusobno. Uvođenjem timskoga rada u redovni nastavni sat, nastavnici bi doprinijeli pozitivnim odnosima među članovima tima što bi u konačnici pridonijelo boljim radnim rezultatima.

8 Postotak se odnosi na objave s ključnom riječi timski rad u sveukupnome broju objava sačuvanih u arhivi.

9 Ne postoji arhiva objava. 
Tablica 3.: Sadržaji navedenih objava

\begin{tabular}{ccc}
\hline SADRŽAJ & Dokumenti & 7 \\
\cline { 2 - 3 } & Radionice & 8 \\
\cline { 2 - 3 } Natjecanja & 12 \\
\cline { 2 - 3 } Slobodne aktivnosti & 7 \\
\hline Fakultativna nastava & 3 \\
\hline Projekti & 22 \\
\hline Drugo & 12 \\
\hline
\end{tabular}

Analiza je pokazala da se timski rad počeo spominjati od 2008. godine, odnosno nakon uvođenja CMS-a za jednostavno postavljanje i ažuriranje internetskih stranica. U razdoblju od uvođenja CARNET-ove usluge do 2019. godine, objave posvećene timskomu radu najzastupljenije su u 2018. godini (Tablica 4).

Tablica 4.: Datumi objava pojma timskoga rada

\begin{tabular}{lll}
\hline DATUMI OBJAVA & 2008. & 1 \\
\cline { 2 - 3 } & 2009. & 1 \\
\cline { 2 - 3 } & 2010. & 1 \\
\hline 2011. & 6 \\
\hline 2012. & 4 \\
\hline 2013. & 3 \\
\hline 2014. & 9 \\
\hline 2015. & 6 \\
\hline 2016. & 10 \\
\hline 2017. & 17 \\
\hline 2018. & 4 \\
\hline
\end{tabular}

Prema navedenim podacima može se zaključiti da je najviše objava vezanih uz timski rad namijenjeno učenicima sa sveukupno 42 objave. Objave su također namijenjene nastavnom osoblju sa 17 objava te drugima s 12 objava (tablica 5.).

Tablica 5.: Namjena pojma timskoga rada

\begin{tabular}{lcc}
\hline NAMJENA & Učenicima & 42 \\
\cline { 2 - 3 } & Nastavnom osoblju & 17 \\
\cline { 2 - 3 } & Drugima & 12 \\
\hline
\end{tabular}


Iako se u hrvatskim odgojno-obrazovnim dokumentima timski rad prvi puta spominje još 2006. godine kao preduvjet ostvarivanja uspjeha gdje bi ravnatelji i stručni suradnici trebali poticati timski rad svih djelatnika i polaznika škole, ove objave dokazuju da se timski rad najviše potiče na najnižoj razini, odnosno među učenicima. Međutim, moramo biti svjesni činjenice da učenici ne mogu utjecati na nastavni sat. Također je važno za naglasiti kako učenici uče prema vlastitome iskustvu pa ako ne vide timski rad u svojoj najbližoj okolini, počevši od organizatora nastave, poticanje timskoga rada među učenicima bit će bezuspješno. To znači da bi objave posvećene timskome radu prvenstveno trebale biti namijenjene zaposlenicima u odgojno-obrazovnom procesu, a tek onda učenicima.

\section{RASPRAVA}

Analiza rezultata pokazala je da se timskom radu ne pridaje veći značaj u objavama koje se mogu naći na mrežnim stranicama srednjih škola u Istarskoj i Brodsko-posavskoj županiji. Tek polovica ispitanih srednjih škola objavljuje tekstove vezane uz timski rad, dok kod polovice škola objave o timskome radu nisu dostupne. Zanimljivo je spomenuti da daleko najviše objava vezanih uz timski rad ima Škola za odgoj i obrazovanje koja se bavi primjerenim programima obrazovanja. Postavlja se pitanje jesu li oni, za razliku od drugih škola, shvatili da će učenici na taj način bolje zadovoljiti svoje potrebe te da će njihov doprinos pozitivno utjecati na motivaciju i samopouzdanje.

Hipoteza da je timski rad dovoljno zastupljen i promoviran na mrežnim stranicama srednjoškolskih institucija u Istarskoj i Brodsko-posavskoj županiji proizišla je iz pretpostavke da je u hrvatskome obrazovnom sustavu došlo do reorganizacije frontalne nastave i primjene suvremenih oblika i metoda poučavanja. Smatralo se da je timski rad ustaljen oblik nastave te da će objave na mrežnim stranicama srednjih škola biti najbrži pokazatelji provođenja timskoga rada u srednjim školama. Međutim, analizom svega navedenoga opovrgavamo hipotezu da je timski rad dovoljno zastupljen i promoviran na mrežnim stranicama srednjih škola Istarske i Brodsko-posavske županije.

Osim navedene analize, promatran je i važeći Zakon o odgoju i obrazovanju u osnovnoj i srednjoj školi (NN 87/08, 86/09, 92/10, 105/10, 90/11, 5/125, 16/12, $86 / 12,126 / 12,94 / 13,152 / 14,07 / 17,68 / 18$ ) od dana 4. 8. 2018. U njemu ne postoji ključna riječ timski rad. Je li naš obrazovni sustav prema Kobayashijevom modelu zaostao na trećem koraku gdje je timski rad formaliziran i nestvaran? U svrhu odgovora na ovo pitanje potrebno je provesti otvoreni intervju s učenicima, nastavnim osobljem, upravom i drugim djelatnicima škole, promatrati nastavne satove 
te druge oblike učioničke i izvanučioničke aktivnosti, kao i rad uprave, provedbu i analizu evaluacije učenika i djelatnika škole, njihova naknadna razmišljanja te ponovno razmotriti dokumente, mrežne stranice i druge oblike komuniciranja.

U istraživanju ovoga rada postoje neka ograničenja. Prvo ograničenje odnosi se na uzorak zbog toga što bi bilo nužno obuhvatiti veći broj županija u Republici Hrvatskoj, pa i druge odgojno-obrazovne institucije (vrtiće, osnovne škole i visokoškolske ustanove). Drugo ograničenje povezano je s metodom istraživanja. Naime, mrežne su stranice srednjih škola analizirane kroz tražilice pojmova i arhive objava, što neke mrežne stranice ne posjeduju. Treće ograničenje dovodimo u vezu s pitanjem je li timski rad dio obrazovne politike, a ono se odnosi na nedovoljno istražene dokumente (kurikulum, dokumenti i propisi dostupni na mrežnim stranicama Agencije za odgoj i obrazovanje, Ministarstva za znanost i obrazovanje i dr.).

\section{ZAKLJUČAK}

Promjene koje se neprestano događaju u društvu utječu i na promjene u odgojno-obrazovnome sustavu. Praćenje trendova razvijenijih europskih zemalja i uvođenje suvremenih modela poučavanja i rada u hrvatske obrazovne institucije temelj je na kojemu se može i mora graditi hrvatsko suvremeno društvo. Kako je timski je rad prepoznat kao sustav uzajamnoga pomaganja i djelotvoran sustav odgajanja, najveći bi se dio problema trebao rješavati upravo njime. Stoga i ne čudi da se spominje kao jedna od sedam osnovnih vještina kvalitetne škole (Glasser, 2005). Nažalost, naše je istraživanje pokazalo da se na mrežnim stranicama hrvatskih srednjoškolskih institucija timskomu radu posvećuje premalo pozornosti. U kontekstu pozitivnoga razvoja mladih, potrebna je promjena pristupa novim generacijama i osposobljavanje za suvremeno tržište rada. Sukladno tome, djelatnike je škole potrebno osvijestiti o njihovoj ulozi koja utječe na socioemocionalni razvoj učenika, kao i o važnosti timskoga rada u kontekstu unapređivanja razumijevanja između potreba škole, roditelja i zajednice. Zbog toga je važno da najviše strukture obrazovne institucije kreiraju timsko ozračje što će se zasigurno pozitivno odraziti na sve ostale strukture. Zaključujemo ovaj rad sljedećim citatom: „Ne postoji savršen pojedinac, ali pravilno sastavljen tim koji omogućava međusobnu sinergiju svih članova može se približiti savršenstvu!" (Antolović, Bošković, 2017, 7) 


\section{LITERATURA}

1. Antolović, K., Bošković, M. (2017). Uspješan timski rad pomoću tipologije članova tima. Zagreb: K\&K Promocija.

2. Buhač, Lj. (2017a). Utjecaj stilova vođenja na pedagoški menadžment škole. Acta Iadertina, 14(1): $81-98$.

3. Buhač, Lj. (2017b). Teorijsko određenje pedagoškog menadžmenta. Acta Iadertina, 14(1): 61-80.

4. Bognar, L., Matijević, M. (2002). Didaktika. Zagreb: Školska knjiga.

5. Bognar, L., Matijević, M. (2005). Didaktika. Zagreb: Školska knjiga.

6. Bruning, L., Saum, T. (2008). Suradničkim učenjem do uspješne nastave. Zagreb: Naklada Kosinj.

7. Carnet (2008). O usluzi /on line/. Preuzeto 23.04.2019. sa: http://www.carnet.hr/cms za skole/o usluzi

8. Brajša, P. (1994). Pedagoška komunikologija (razgovor, problemi i konflikti u školi), Zagreb: Školske novine.

9. Carle, U. (2010). Kooperation und Teamarbeit in der modernen Schule. U: U. Carle (ur.), Gesunde Schule: Öffnung - Koopreation - Bewegung - Integration; beiträge zur Tagung "Gesunde Schule“ (79-96). Frankfurt am Main: Deutsches Institut für Internationale Pädagogische Forschung.

10. Džubur, S. (2003). Uloga ljudskih resursa u suvremenom poslovanju. Naše more: znanstveni časopis za more i pomorstvo, 50(1-2): 44-49.

11. Egolf, D. B., Chester, S. L. (2013). Forming, storming, norming, performing. Successful Communication in Groups and Teams, Bloomington: Universe.

12. Glasser, W. (2005). Kvalitetna škola: škola bez prisile. Zagreb: Educa.

13. Katunarić, V. (1999). Informacijsko doba i homofilija: rasprava o doprinosu sociologije mreža. Revija za sociologiju, 30(1-2): 65-80.

14. Kauffeld, S. (2014). Arbeits-, Organisations- und Personalpsychologie für Bachelor, Berlin: Heidelberg: Springer - Verlag.

15. Maxwell, C. J. (2003). 17 neosporivih pravila za uspješan timski rad. Varaždin: Katarina Zrinski.

16. Ministarstvo obrazovanja znanosti i sporta [MZOS] (2006). Nastavni plan i program za osnovnu školu. Zagreb: MZOS.

17. Ministarstvo znanosti, obrazovanja i sporta [MZOS] (2008). Zakon o odgoju i obrazovanju u osnovnoj i srednjoj školi. Zagreb: MZOS.

18. Nikić, M. (2004). Temeljna načela timskog rada. Diacovensia, 12(1): 115-129.

19. Ravlić, J. (1996). Timsko praćenje osobina i sposobnosti učenika osnovne škole. U: H. Vrgoč (ur.), Zbornik radova sabora hrvatske pedagogije, Zagreb, 1996 (178-185). Zagreb: Pedagogija i hrvatsko školstvo: jučer i danas, za sutra.

20. Skupnjak, D. (2018). Timski rad i supervizija školskih timova. Varaždinski učitelj - digitani stručni časopis za odgoj i obrazovanje, 1(1): 1-11.

21. Tipurić, D. (1999). Konkurentska sposobnost poduzeća, Zagreb: Sinergija. 
22. Tudor, G., Srića, V. (2006). Menadžer i pobjednički tim: čarolija timskog rada. 3. izd. Zagreb: M.E.P. Consult.

23. Vidović, B., Matas, V., Puljiz, M. (2009). Strateški menadžment u školstvu. U: V. Filipović, H. Friederichs (ur.), Ravnatelj škole - Upravljanje - Vođenje (11-40). Zagreb: Agencija za odgoj i obrazovanje i Nederlandse School voor Onderwijsmanagement [NSO].

24. Waldow, F. (2012). Taylorismus im Klassenzimmer: John Franklin Bobbitts Vorschläge zur standards - based reform. U: Zeitschrift für Pädagogik 58, Frankfurt: BELTZ. 


\title{
ANALYSIS OF TEAMWORK REPRESENTATION ON OFFICIAL WEBSITES HIGH SCHOOL INSTITUTIONS IN ISTRIAN AND BROD-POSAVSKA COUNTY
}

\begin{abstract}
In today's cultural pluralistic society teamwork has become the subject of a successful business so it started to apply in educational institutions also. One way of showing the school image is through school websites. Their analysis of the content can create a picture about contributing the importance of teamwork in schools. The aim of this work is to determine how often, in which context and to whom are intended published texts with the keyword "teamwork" on websites of the highschools in Istrian and Brod-Posavska county. The purpose of the work is collecting the data about representation key word "teamwork" on websites of mentioned schools. Analysis results gave an answer to the question if the teamwork had became part of the highschools educational policy. Unfortunately, it turned out that highschools do not attach significance to the teamwork on their websites.
\end{abstract}

Key words: highschools, websites, educational institutions, educational politics. 